Michał Ja neczek

(Leszno)

dr, bibliooverkill@wp.pl

\title{
Utracony księgozbiór ks. Stanisława Kozierowskiego
}

Podczas prac nad Katalogiem starych druków Archiwum Państwowego w Poznaniu ${ }^{1}$ natknąłem się na wiele książek, które na odwrocie karty tytułowej miały znak „K” wykonany ołówkiem. Przez dłuższy czas sądziłem, że tak oznaczone mogą być książki po księdzu profesorze Stanisławie Kozierowskim. Trop ten okazał się błędny, kiedy zacząłem drążyć temat i dotarłem do odpowiednich dokumentów. W niniejszym artykule zaprezentuję wyniki moich badań dotyczących dawnej biblioteki Kozierowskiego.

Temu wielkiemu poznańskiemu uczonemu poświęcono liczne opracowania, rzadko kiedy też bywa pomijany w biogramach słownikowych. Warto uporządkować te materiały, wskazać, które z nich są najbardziej przydatne dla dalszych badań nad życiem i twórczością naukową Stanisława Kozierowskiego, a także nakreślić (choć zdecydowanie wykracza to poza zakres tematyczny niniejszego artykułu) kierunek tych badań, które pozwolą jeszcze lepiej poznać wielkopolskiego profesora. Pierwsze artykuły miały charakter wspominkowy i powstały zaraz po śmierci Kozierowskiego; były to teksty: Ludwika Gomolca, Stanisława Urbańczyka i Aleksandra Króla² . Przez następne dwadzieścia lat właściwie niczego ciekawego o uczonym nie napisano i dopiero bardzo rzetelny biogram autorstwa Urbańczyka

\footnotetext{
${ }^{1}$ Zob.: M. Janeczek, Katalog starych druków Archiwum Państwowego w Poznaniu, Poznań 2016.

2 Zob.: L. Gomolec, Prace badawcze ks. Stanistawa Kozierowskiego, „Przegląd Zachodni” 1949, nr 1-2, s. 88-90; S. Urbańczyk, Ks. Stanistaw Kozierowski jako onomasta, "Przegląd Zachodni” 1949, nr 1-2, s. 91-93; wersja franc.: „Bulletin. Académie Polonaise des Sciences et des Lettres...” 1949, nr 3, s. 30-34; A. Król, Śp. ks. kanonik S. Dołęga-Kozierowski, „Wiadomości Archidiecezji Gnieźnieńskiej” 1949, nr 1-3, s. 35-36.
} 
w Polskim słowniku biograficznym ${ }^{3}$ sprawił, że nazwisko Kozierowskiego do teraz uwzględniane jest $\mathrm{w}$ słownikach i encyklopediach. $\mathrm{Z}$ tych ważniejszych należałoby wymienić w porządku chronologicznym: Wielkopolski słownik biograficzny, Biogramy uczonych polskich, Uczeni polscy XIX-XX stulecia, Encyklopedię katolicka, Wielka encyklopedię PWN $N^{4}$. W 1973 r. ukazała się opasła praca zbiorowa pod tytułem Nauka w Wielkopolsce; autorzy tekstów poświęconych rozwojowi poszczególnych dziedzin wiedzy $\mathrm{w}$ tej prowincji odwoływali się do dorobku naukowego ks. Kozierowskiego - jego nazwisko przywołane zostało na siedemnastu stronicach ${ }^{5}$. Bardzo przydatny przy kwerendach prowadzonych w Archiwum Polskiej Akademii Nauk jest artykuł Jacka Latzke, gdyż w części opisowej zawiera ogólną charakterystykę materiałów rękopiśmiennych, w części katalogowej zaś - szczegółowy przegląd zawartości inwentarza ${ }^{6}$. Zamieszczony w periodyku "Życie i Myśl" tekst Bernarda Piotrowskiego - pierwszy tak dogłębny w tej materii - omawia dokonania językoznawcy na polu naukowym wraz z przywołanymi komentarzami uczonych współczesnych Kozierowskiemu; życiorys zarysowany raczej skrótowo ${ }^{7}$. Niewielki objętościowo, ale cenny z uwagi na odnotowaną współpracę Kozierowskiego z „Kroniką Gostyńską”, jest artykuł autorstwa Józefa Sprutty, przygotowany dla regionalnego czasopisma „Przyjaciel Ludu" 8 . Dwukrotnie omówił i ocenił dorobek onomastyczny autora Atlasu nazw geograficznych Stowiańszczyzny zachodniej Bogdan Walczak; w obu tekstach nawiązuje do refleksji poczynionych przez Urbańczyka, przy czym w nowszym potraktował temat nieco szerzej ${ }^{9}$. Najwięcej informacji bio-

${ }^{3}$ S. Urbańczyk, hasło Kozierowski Stanisław, [w:] Polski słownik biograficzny, pod red. E. Rostworowskiego, t. 14, Wrocław 1968-1969, s. 628-629.

4 J. Latzke, hasło Kozierowski Stanistaw, [w:] Wielkopolski stownik biograficzny, pod red. A. Gąsiorowskiego i J. Topolskiego, Warszawa-Poznań 1981, s. 371; Biogramy uczonych polskich, cz. 1, Nauki społeczne, z. 2, oprac. A. Śródka i P. Szczawiński, Wrocław 1984, s. 168-170; A. Śródka, Uczeni polscy XIX-XX stulecia, t. 2, Warszawa 1995, s. 320-321. - E. Gigilewicz, hasło Kozierowski Stanistaw, [w:] Encyklopedia katolicka, pod red. B. Miguta, t. 9, Lublin 2002, kol. 1108-1109; Wielka encyklopedia PWN, t. 14, pod red. J. Wojnowskiego, Warszawa 2003, s. 504.

${ }^{5}$ Nauka w Wielkopolsce, pod red. G. Labudy, Poznań 1973, s. 31, 269, 355, 484-485, 496, 509$-511,517,538,784,798,801,812,848,866$.

${ }^{6}$ J. Latzke, Materiaty Stanisława Kozierowskiego, „Biuletyn Archiwum Polskiej Akademii Nauk" 1983, nr 26, s. 8-87.

${ }^{7}$ B. Piotrowski, Ks. Stanistaw Kozierowski - duchowny, uczony, patriota, „Życie i Myśl” 1987, nr 3-4, s. 148-159.

${ }^{8}$ J. Sprutta, Ksiądz Stanistaw Kozierowski, „Przyjaciel Ludu” 1991, z. 4, s. 18-20. Kilka lat później, z okazji pięćdziesiątej rocznicy śmierci kapłana, Sprutta podał do druku tekst niemalże identyczny. Zob.: „Przegląd Zachodniopomorski” 1999, nr 4, s. 217-220.

9 Por.: B. Walczak, Ksiadz Stanistaw Kozierowski jako onomasta, „Kronika Wielkopolski” 1995, nr 3, s. 36-44; tegoż, Refleksje nad dziełem księdza Stanistawa Kozierowskiego, [w:] W Trzemesznie i nie tylko..., pod red. B. Walczaka, Poznań 2006, s. 133-148. 
graficznych zawierają artykuły Jana Leśnego ${ }^{10}$ i Stanisława Nawrockiego ${ }^{11}$; szczególnie drugi z autorów uwzględnił pomijane dotąd materiały archiwalne oraz pozyskał niektóre informacje od członków rodziny Kozierowskiego, co pozwoliło m.in. szerzej potraktować okres okupacji hitlerowskiej w życiu księdza. Na podstawie wspomnianych opracowań Ryszard Marciniak napisał w krótkim odstępie czasowym dwa teksty różniące się tylko nieistotnymi szczegółami ${ }^{12}$. Obchody setnej rocznicy przybycia Kozierowskiego do parafii skórzewskiej zaowocowały m.in. dwoma publikacjami ${ }^{13}$; szczególnie godna polecenia badaczom jest monografia Danuty Konieczki-Śliwińskiej, która omawia całe życie księdza profesora wraz z jego osiągnięciami zawodowymi i naukowymi, aczkolwiek - zgodnie z tytułem książki - mocniej koncentruje się okresie skórzewskim, odnotowując wiele nieznanych wcześniej faktów życiorysowych. Ostatnie, jak dotąd, informacje o wybitnym językoznawcy przedstawili: Danuta Konieczka-Śliwińska (Ksiądz profesor Stanisław Kozierowski - życie i dziatalnośc), Artur Kijas (Stanistaw Kozierowski - historyk, genealog, wspótzałożyciel Uniwersytetu Poznańskiego) i Bogdan Walczak (Onomastyczny dorobek księdza Stanisława Kozierowskiego) ${ }^{14}$.

Ten pobieżny przegląd literatury przedmiotowej nie zwalnia nas z obowiązku przypomnienia kilku ważnych faktów z życia Kozierowskiego ${ }^{15}$. Urodził się 28 września 1874 r. w Trzemesznie jako syn mistrza szewskiego Floriana i Antoniny z domu Buszkiewicz. Przyszły profesor uważał, że ojciec wywodził się ze szlachty, toteż używał w późniejszym czasie przy nazwisku klejnotu herbowego Dołęga. Uczył się najpierw w progimnazjum trzemeszeńskim, maturę uzyskał w roku 1896 w Gimnazjum św. Marii Magdaleny w Poznaniu. Przez kolejne cztery lata studiował w seminarium duchownym w Poznaniu i Gnieźnie, gdzie 12 listopada 1899 r. przyjął święcenia kapłańskie. Pracował na stanowisku wikariusza we Wronkach (1899-1901), w Gostyniu (1901-1903) i w Ostrzeszowie (1903-1905), a następnie - już jako proboszcz działał w Siemianicach (1905-1910), w Skórzewie (1910-1929) i w Winnej Górze

${ }^{10}$ J. Leśny, Stanisław Kozierowski (1874-1949), [w:] Wybitni historycy wielkopolscy, pod red. J. Strzelczyka, Poznań 2010, s. 213-225.

11 S. Nawrocki, Ks. prof. Stanistaw Kozierowski (1874-1949), [w:] Zrodziła ich Ziemia Mogileńska, pod red. C. Łuczaka, Poznań 1997, s. 163-175.

12 Por.: R. Marciniak, Ksiądz Stanistaw Kozierowski (1874-1949), [w:] W hołdzie naszym Antenatom, pod red. J. Laskowskiego i G. Łukomskiego, Poznań 2004, s. 93-108; tegoż, Ksiadz Stanistaw Kozierowski (1874-1949) - życie i dzieło, [w:] W Trzemesznie i nie tylko..., s. 119-132.

13 Zob.: P.M. Dziembowski, Proboszczowie parafii świętego Marcina i świętego Wincentego w Skórzewie, Skórzewo 2010, s. 88-91; D. Konieczka-Śliwińska, Ks. Stanisław Kozierowski - proboszcz parafii skórzewskiej (1910-1929), Skórzewo 2010.

${ }^{14}$ Zob.: "Nie zgaśnie pamięć o Waszej pracy”. Założyciele Uniwersytetu Poznańskiego, pod red. A. Pihan-Kijasowej i D. Konieczki-Śliwińskiej, Poznań 2016, s. 27-58.

${ }^{15}$ Informacje biograficzne zebrano na podstawie wymienionych wyżej publikacji. 
(1929-1949). W uznaniu dla zasług prymas August Hlond w 1931 r. mianował go kanonikiem honorowym kapituły metropolitalnej w Gnieźnie.

Oprócz pracy duszpasterskiej Stanisław Kozierowski poświęcił się z całą mocą pracy naukowej. Związał się z licznymi towarzystwami naukowymi, m.in.: Towarzystwem Historycznym we Lwowie (1908), Polskim Towarzystwem Heraldycznym (1911), Polską Akademią Umiejętności (1936), najwcześniej jednak i najsilniej współpracował z Towarzystwem Przyjaciół Nauk w Poznaniu, którego członkiem został w 1903 r., a przewodniczącym Wydziału Historyczno-Literackiego - w 1917 r. Liczne talenty Kozierowskiego dostrzegł Heliodor Święcicki, który wprowadził go do uniwersyteckiej Komisji Organizacyjnej w listopadzie 1918 r. Po uzyskanej w 1920 r. habilitacji powołano Kozierowskiego na etat docenta w sekcji historycznej Wydziału Filozoficznego Uniwersytetu Poznańskiego. Prowadził wykłady do wybuchu II wojny światowej na temat dziejów Słowiańszczyzny zachodniej oraz germanizacji plemion zamieszkujących te tereny. W 1938 r. mianowano go profesorem tytularnym Wydziału Humanistycznego. Podczas okupacji hitlerowskiej narażony był na liczne nieprzyjemności, głównie z uwagi na głoszone poglądy i prace badawcze o antyniemieckim wydźwięku. Po wojnie na Uniwersytet już nie wrócił, uczestniczył natomiast w pracach Komisji Ustalania Nazw Miejscowości przy ministrze administracji publicznej, której celem było spolszczenie nazw miejscowych na Ziemiach Odzyskanych.

Z wielką łatwością przychodziła mu nauka języków obcych, zarówno nowożytnych (niemiecki, angielski, francuski, fiński, litewski, rosyjski, czeski, włoski), jak i starożytnych (łaciński, staro-cerkiewno-słowiański, gocki, staropruski, staroirański, sanskryt) - umiejętność tę wykorzystywał do swych badań naukowych. Początkowe fascynacje światem starożytnym przerodziły się dość szybko w trwałe zainteresowania średniowieczną Słowiańszczyzną; Kozierowski prowadził badania ukierunkowane historycznie z zakresu onomastyki, fizjografii, geografii, genealogii, heraldyki, starał się również rozkrzewiać wiedzę etymologiczną. Owocem jego pasji badawczej były następujące publikacje: ośmiotomowy cykl ukazujący się pod wspólnym tytułem Badania nazw topograficznych... (1914-1939), obejmujący obszar historycznej Wielkopolski; znacznie bardziej ambitny i trudniejszy w realizacji Atlas nazw geograficznych Słowiańszczyzny zachodniej (1934-1937); ukazujące się głównie w periodykach Studia nad pierwotnym rozsiedleniem rycerstwa wielkopolskiego (1913-1933) zamknęły się w monografiach dwunastu rodów rycerskich; pod wieloma względami nowatorskie było studium Obce rycerstwo w Wielkopolsce w XIII-XVI wieku (Poznań 1929); trzyczęściowa seria Nieznane zapiski heraldyczne... (1915-1928) również ogłoszona została w czasopismach; wybitny wkład w poznanie dziejów parafii wielkopolskich przynoszą Szematyzm historyczny ustrojów parafialnych dzisiejszej archidiecezji gnieźnieńskiej (Poznań 1934) i bliźniaczy tytuł o archidiecezji poznańskiej (Poznań 1935); publika- 
cja w dwóch częściach Nazwiska, przezwiska, przydomki i imiona polskie niektórych typów słowotwórczych (Poznań 1938-1948) porządkowała materiał wynotowany z ksiąg ziemskich i grodzkich; ponadto wiele pomniejszych tekstów ogłosił Kozierowski w czasopismach: „Slavia Occidentalis”, „Miesięcznik Herladyczny” i „Kronika Gostyńska”.

W swoim 74-letnim życiu ks. Kozierowski uzbierał pokaźną liczbę książek; gromadził szczególnie źródła drukowane do historii średniowiecznej Polski, które wykorzystywał w dalszym ciągu do twórczej pracy naukowej. We wszystkich opracowaniach powtarza się informacja, że cenna biblioteka proboszcza Winnej Góry liczyła ok. dziesięć tys. tomów. Tom w rozumieniu 'pojedynczy egzemplarz książki' obejmowałby zarówno wydawnictwa wielotomowe (każdy tom liczony osobno), jak i klocki introligatorskie (w jednym tomie kilka dzieł). Przed śmiercią w akcie ostatniej woli Kozierowski zapisał całą bibliotekę naukową oraz spuściznę rękopiśmienną Archiwum Państwowemu w Poznaniu, z którym utrzymywał dobre stosunki od chwili, kiedy z ramienia Rady Ludowej powiatu poznańskiego mianowany został kuratorem tejże instytucji; wcześniej zresztą wielokrotnie korzystał z bogatych zbiorów Archiwum ${ }^{16}$, toteż był na tyle kompetentny, by podjąć się tej funkcji. Do tej pory fakt ten tylko zdawkowo pojawiał się w opracowaniach, a przecież ta wielka donacja rozsławiła imię poznańskiego uczonego na równi z jego dorobkiem naukowym.

Żadna poznańska książnica nie ucierpiała w czasie II wojny światowej tak, jak biblioteka Archiwum Państwowego - w wyniku działań wojennych uległa niemal całkowitej zagładzie. W ogniu zgorzały zbiory liczące dwadzieścia tys. tomów. Dyrektor placówki Kazimierz Kaczmarczyk wiedział, że $\mathrm{w}$ tym trudnym powojennym czasie tylko duża donacja może zrekompensować stratę. Wystosował wiele próśb o pomoc; w listopadzie 1945 r. wysłał list do ks. Stanisława Kozierowskiego, w którym m.in. pisał:

Nasza biblioteka archiwalna, niestety, w całości spłonęła podpalona przez Niemców, jesteśmy pozbawieni zupełnie książek, co jest dla nas prawdziwą katastrofą, tym większą, że był to piękny zbiór dzieł źródłowych i opracowań do Wielkopolski, a dziś nie jesteśmy w stanie nowej biblioteki odtworzyć ${ }^{17}$.

Proboszcz wsłuchał się w apel dyrektora Kaczmarczyka i postanowił podarować Archiwum swoje zbiory. Pierwszą wzmiankę o tym zamiarze odnaj-

${ }^{16}$ Regularne kwerendy prowadził od 1910 r., kiedy osiadł w Skórzewie, skąd dojeżdżał rowerem (ok. 15 km) do Poznania. Zob.: J. Leśny, Stanistaw Kozierowski (1874-1949), [w:] Wybitni historycy..., s. 217.

17 PAN Archiwum (Poznań): Materiały Stanisława Kozierowskiego, list Kaczmarczyka do Kozierowskiego z 10 listopada 1945 roku, sygn. P.III-15, j.a. 335, k. 11-12. 
dujemy w sprawozdaniu z 30 marca 1946 r. z podróży służbowej archiwisty Franciszka Paprockiego do Winnej Góry.

Rękopisy i archiwalia własne i rodziny - pisał Paprocki - pragnie przekazać Archiwum Państwowemu w Poznaniu bez żadnych zastrzeżeń. Bibliotekę zaś, stanowiącą cenny skarbiec dla badań topograficzno-językoznawczych całej Słowiańszczyzny gotów jest oddać Archiwum [...] pod warunkiem zabezpieczenia dożywocia swej długoletniej gospodyni, dziś już osobie w podeszłym wieku' ${ }^{18}$.

Do sprawozdania dołączony został pobieżny spis książek i materiałów rękopiśmienno-archiwalnych wykonany ręką Kozierowskiego. Już wcześniej, bo w lutym 1946 r., uczony ofiarował bibliotece archiwalnej szesnaście woluminów z prywatnej kolekcji ${ }^{19} .12$ października Kaczmarczyk wysłał pismo do Ministerstwa Oświaty, w którym informował o możliwości przejęcia biblioteki ks. Kozierowskiego po jego śmierci; jedynym warunkiem postawionym przez właściciela było wsparcie materialne dla gospodyni Julii Owoc. W ostatnim akapicie dyrektor Archiwum Państwowego wydał własną opinię na temat tejże oferty:

Propozycja ks. Kozierowskiego jest umiarkowana, zwłaszcza jeśli się weźmie pod uwagę zarówno wiek i stan zdrowia (chora na cukrzycę) rencistki, jak i wiek jego samego (72 lata), przeto stawiam wniosek o przyjęcie propozycji i przygotowanie odpowiedniej punktacji kontraktu z ks. Kozierowskim, a następnie po dojściu z nim do porozumienia zawarcie $\mathrm{z}$ nim kontraktu ${ }^{20}$.

W testamencie sporządzonym 13 marca 1947 r. przez ks. Kozierowskiego pojawiają się pierwsze konkrety. Obiecuje on przekazać po swoim zgonie całą bibliotekę, zbiory kartograficzne, archiwalne i rękopiśmienne na własność Archiwum Państwowego „pod tym warunkiem, że Rząd Polski wypłacać będzie [...] emeryturę Julii Owoc w równowartości trzech kwintali pszenicy miesięcznie" ${ }^{21}$. Testament stał się powodem długich pertraktacji między Ministerstwem Oświaty a władzami Archiwum z powodu nieścisłości zapisów dotyczących ewentualnego wsparcia finansowego dla darczyńcy, gdyby kiedykolwiek przyszło mu żyć w ubóstwie, a poznańska instytucja nie udzieliła stosownej pomocy. Ustalenia trwały do początku roku 1949; dopiero wte-

18 APP: Biblioteka (Biblioteka ks. Kozierowskiego) 1946-1950, sprawozdanie Franciszka Paprockiego z podróży służbowej do Winnogóry 30 III 1946 roku, sygn. 746, k. 1v.

19 J. Matysiak, Działalność bibliotekarska i bibliofilska profesora Kazimierza Kaczmarczyka (1878-1966), dyrektora Archiwum Państwowego w Poznaniu, „Biblioteka” 2011, nr 15, s. 63. Były to jego własne publikacje.

${ }^{20}$ APP: Biblioteka (Biblioteka ks. Kozierowskiego) 1946-1950, pismo Kaczmarczyka do Ministerstwa Oświaty z 12 X 1946 roku, sygn. 746, k. 9r.

${ }^{21}$ APP: Biblioteka (Biblioteka ks. Kozierowskiego) 1946-1950, Moja ostatnia wola, sygn. 746, k. 16r. 
dy wysłano pismo do Kozierowskiego, że Ministerstwo Oświaty przystaje na jego warunki.

Po śmierci Kozierowskiego Archiwum Państwowe szybko przystąpiło do zabezpieczania zbiorów. Misję tę powierzono Leonowi Siuchnińskiemu, kierownikowi pracowni naukowej i opiekunowi biblioteki archiwalnej. Dzięki jego sprawozdaniom potrafimy odtworzyć to, co działo się z biblioteką w kolejnych miesiącach, aż do ostatecznego przejęcia jej przez poznańską placówkę. I tak, w ósmym dniu po śmierci proboszcza Winnej Góry donosił, że rodzina, pragnąc uszanować wolę zmarłego, nie sprzeciwia się przejęciu biblioteki przez Archiwum Państwowe w Poznaniu; 19 lutego oznajmił, że rozpoczął sporządzanie inwentarza książek. Z raportu datowanego na 12 marca dowiadujemy się, że pojawiła się pewna kontrpropozycja w odniesieniu do zbiorów bibliotecznych:

Kuria Metropolitalna w Gnieźnie w rozmowie telefonicznej, prowadzonej w dniu 10 marca, nakłaniała ob. Julię Owoc do przekazania biblioteki Kurii w Gnieźnie, obiecując jej dać lepsze warunki niż Państwo przez zapewnienie ponad to mieszkania i utrzymanie na probostwie w Winnejgórze. Na te propozycje ob. Julia Owoc nie zgodziła się tłumaczeniem, że byłoby to wbrew woli zmarłego ${ }^{22}$.

22 marca przybył do Winnej Góry nowy proboszcz - ks. Lucjan Berger. Ponieważ biblioteka mieściła się w centralnym pokoju, a każde drzwi prowadzące doń były zamknięte na klucz, utrudniało to normalne funkcjonowanie gospodarzowi probostwa. Siuchniński obiecał, że „natychmiast po załatwieniu wszelkich formalności sądowych i skarbowych biblioteka przewieziona zostanie do Poznania"23. Postępowanie spadkowe wszczęte zostało przez Sąd Grodzki w Środzie Wlkp. na wniosek Archiwum Państwowego z 9 lutego 1949 r. W kolejnym sprawozdaniu z 5 kwietnia Siuchniński pisze, że prócz wyceny majątku po ks. Kozierowskim sąd nakazał jeszcze sporządzenie inwentarza, który był konieczny w myśl postanowień o prawie spadkowym ${ }^{24}$. Inwentarz taki, jak już wspomniano, powstawał, a opiekun biblioteki regularnie informował przełożonych o postępach w tej kwestii.

Stwierdzenie prawa do spadku po ks. Kozierowskim Sąd Grodzki w Środzie Wlkp. wydał 4 czerwca. Prace nad inwentarzem Siuchniński ukończył 10 lipca; według jego raportu ostatnia zainwentaryzowana książka nosiła nu-

22 Tamże, sprawozdanie Leona Siuchnińskiego z podróży służbowej do Winnogóry 12 III 1949 roku, sygn. 746, k. 46r.-46v.

${ }^{23}$ Tamże, sprawozdanie Leona Siuchnińskiego z podróży służbowej do Winnogóry 24 III 1949 roku, sygn. 746, k. 58r.

24 Tamże, sprawozdanie Leona Siuchnińskiego z podróży służbowej do Środy Wlkp. 5 IV 1949 roku, sygn. 746, k. 69r. 
mer $4078^{25}$. Ostatnie przewidziane w prawie procedury zrealizowano w drugiej połowie sierpnia; Siuchniński pisał wówczas w sprawozdaniu:

W dniu 26 sierpnia sporządził komornik sądowy Ziemięcki w mojej obecności protokół z dokonania spisu inwentarza biblioteki w Winnejgórze. Dnia 29 sierpnia zabrałem całą bibliotekę oraz regały na 2 samochodach 7-tonowych do Poznania. Bibliotekę umieszczono chwilowo w sali $15^{26}$.

Bardzo ciekawym dokumentem jest zeznanie podatkowe za rok 1949, z którego wynika, że „biblioteka, składająca się z 4078 dzieł w 6918 tomach, planów 982, rękopisów, archiwaliów i wydawnictw ks. kan. Stan. Kozierowskiego (541 poz.) oraz z 13 regałów", warta była w dniu złożenia zeznania trzy mln zł ${ }^{27}$. Pozostałe rzeczy, takie jak: szafa trzydrzwiowa, łóżko dębowe, bufet, umywalnia z płytą marmurową i lustrem, dwa obrazy czy stól, wycenione zostały w sumie na 61500 zł i trafiły do rąk Julii Owoc. Trzeba tu nadmienić, że do 1951 r. Archiwum Państwowe mieściło się w kilku pomieszczeniach byłego zamku cesarskiego i w budynku przy ul. Stawnej. Zapewne nie od razu materiały po ks. Kozierowskim trafiły do pokoju nr 23 w odbudowanym gmachu dawnego Sądu Apelacyjnego w Poznaniu, który stał się siedzibą Archiwum Państwowego.

Z powodu konieczności uzyskania wolnej przestrzeni na akta podjęta została decyzja o rozproszeniu archiwaliów i ksiąg otrzymanych od ks. Kozierowskiego. Obecnie materiały rękopiśmienne o objętości ok. 6 mb. przechowywane są w budynku Archiwum Polskiej Akademii Nauk - Oddział $\mathrm{w}$ Poznaniu, do którego trafiły $\mathrm{w}$ formie depozytu na mocy umowy zawartej 20 marca 1961 r. pomiędzy dyrektorem Archiwum Miasta Poznania i Województwa Poznańskiego Czesławem Skopowskim a kierownikiem Archiwum PAN Kazimierzem Ślaskim ${ }^{28}$. Prace porządkowe nad spuścizną Kozierowskiego prowadził Jan Szajbel w latach 1962-1963, 1970-1973; kontynuował je Jacek Latzke, który ukończył inwentarz w 1978 r. po scaleniu niektórych jednostek.

Materiały rękopiśmienne St. Kozierowskiego charakteryzują się dużą różnorodnością. Obok prac naukowych nie publikowanych, w spuściźnie znajdują się bogate materiały warsztatowe, oraz dotyczące działalności w instytucjach, towarzystwach nauko-

25 Tamże, sprawozdanie Leona Siuchnińskiego z podróży służbowej do Środy Wlkp. i Winnejgóry 20 VII 1949 roku, sygn. 746, k. 85r.

26 Tamże, sprawozdanie Leona Siuchnińskiego z podróży służbowej do Środy Wlkp. i Winnejgóry 31 VIII 1949 roku, sygn. 746, k. 88r.

27 Tamże, zeznanie do podatku od nieodpłatnego nabycia praw majątkowych za 1949 rok, sygn. $746, \mathrm{k} .102$ r.

${ }^{28}$ J. Latzke, Materiaty Stanisława Kozierowskiego, „Biuletyn Archiwum Polskiej Akademii Nauk" 1983, nr 26, s. 11. 
wych i społeczno-politycznych, jak również materiały biograficzne oraz korespondencja naukowa ${ }^{29}$.

Latzke podzielił te materiały na sześć grup; opatrzone zostały sygnaturą P.III-15. Szczególną wartość dla niniejszych rozważań przedstawia grupa III (materiały biograficzne), do której zakwalifikowano: dokumenty osobiste, autobiografie, pisma gospodarczo-majątkowe, wśród nich zaś - spis książek z biblioteki uczonego (jednostki 313-315). Właśnie skonfrontowanie tego spisu ze stanem faktycznym pozwoli „wychwycić” książki przekazane przez Kozierowskiego do Archiwum.

Dokumenty rękopiśmienne zatem spoczywają w magazynach Archiwum PAN, natomiast księgozbiór prywatny Kozierowskiego stał się podstawą odrestaurowanej biblioteki Archiwum Państwowego i mieści się obecnie w budynku przy ul. 23 Lutego. A w zasadzie mieścił się do 1961 r., kiedy został bezpowrotnie rozproszony: „dzieła dotyczące dziejów Wielkopolski pozostały w Archiwum jako cenne uzupełnienie jego biblioteki fachowej, dotyczące slawistyki przekazano Instytutowi Słowianoznawstwa PAN, a beletrystykę - Bibliotece Uniwersyteckiej w Poznaniu"30. Niezależnie od Archiwum Państwowego drobne archiwalia związane z Kozierowskim znalazły się w Bibliotece Raczyńskich, Bibliotece Poznańskiego Towarzystwa Przyjaciół Nauk oraz w Kurii Metropolitalnej w Gnieźnie.

O darach dla Instytutu Slawistyki PAN wspomina Andrzej Wędzki ${ }^{31}$.

Powróćmy jeszcze na chwilę do zasobności biblioteki, gdyż z podanych informacji wynika pewna rozbieżność. Jak pamiętamy, literatura przedmiotu określa liczbę tomów na ok. dziesięć tys. Liczba ta - mocno zawyżona - mogła wziąć się ze wstępnych szacunków. Spis zawartości biblioteki bowiem, wykonany przez Siuchnińskiego, obejmuje 4078 pozycji, które po dokładnym zliczeniu dały wynik 6908 tomów ${ }^{32}$. Potwierdza to komornik Zygmunt Ziemięcki, który z polecenia sądu sporządził protokół i dołączył doń repertorium dzieł $\mathrm{w}$ formie maszynopisu ${ }^{33}$.

Nowe druki dość szybko zostały opracowane i udostępnione użytkownikom, gorzej przedstawia się sprawa ze starymi drukami - spotkał je ten

29 Tamże, s. 11-12.

${ }^{30}$ S. Nawrocki, dz. cyt., s. 175.

${ }^{31}$ A. Wędzki, Słownik starożytności słowiańskich z perspektywy pół wieku, [w:] 50 lat slawistyki w Polskiej Akademii Nauk (1954-2004), pod red. K. Handke, Warszawa 2004, s. 203.

32 PAN Archiwum (Poznań): Materiały Stanisława Kozierowskiego, biblioteka - spis zawartości, sygn. P.III-15, j.a. 313-315. Główny spis Siuchnińskiego ma chaotyczny układ, ponieważ obejmuje nie tylko druki zwarte, ale też czasopisma, „wycinki z różnych gazet” (poz. 2164), sprawozdania i materiały z posiedzeń towarzystw (poz. 3788), mapy i plany miast oraz rękopisy (poz. 3513). Na końcu osobno odnotowano rękopisy oraz plany i mapy.

33 APP: Archiwum Państwowe w Poznaniu (akta własne), protokół czynności Komornika Sądu Grodzkiego w Środzie, sygn. 872. 


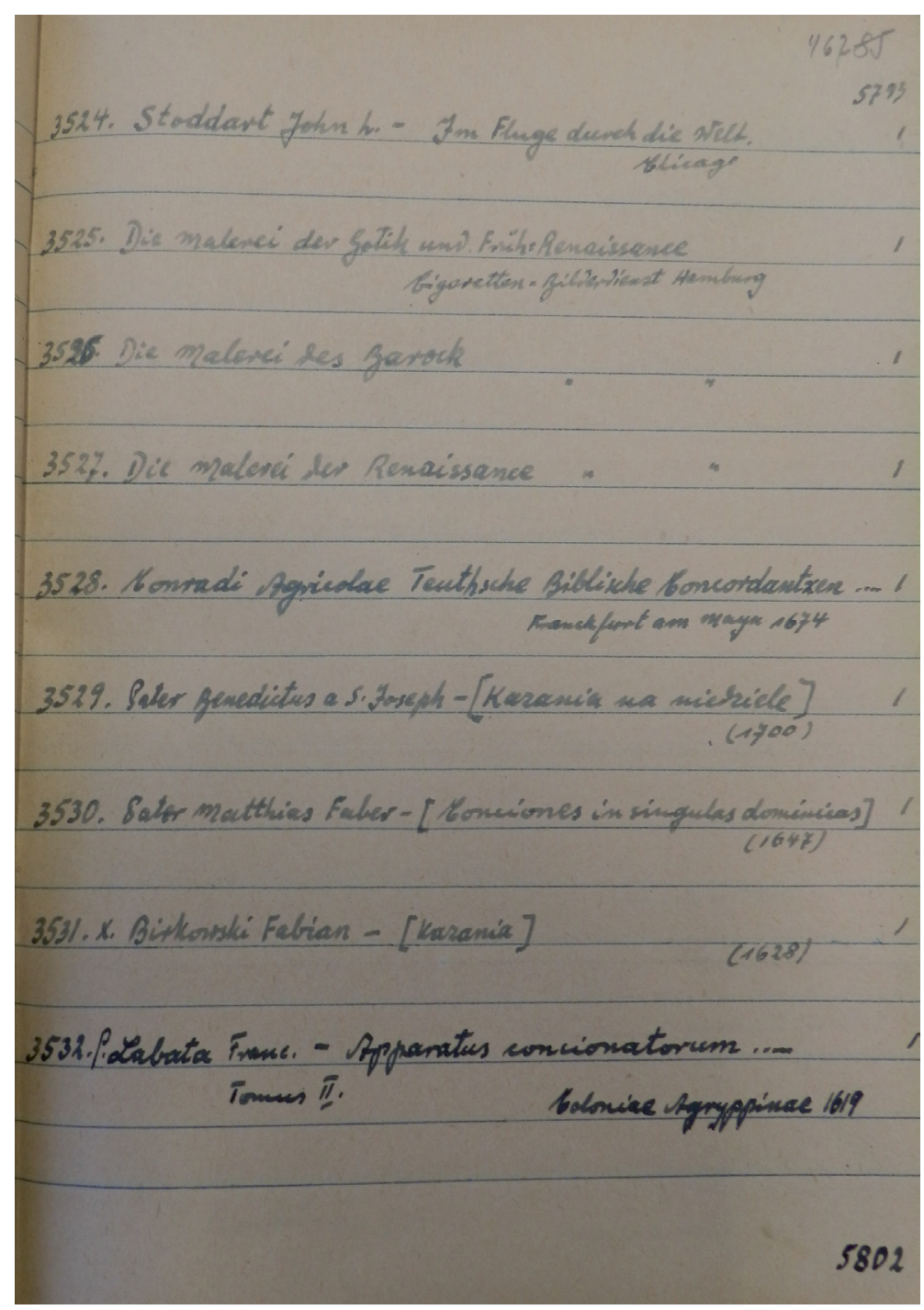

Fot. 1. Stronica z odręcznie wykonanego przez Leona Siuchnińskiego spisu książek po ks. Stanisławie Kozierowskim

sam los, co książki z dawnej biblioteki braci czeskich ${ }^{34}$. Wiadomo było, że poznańska instytucja posiada cenne tomy, jednak szczegóły znali tylko nieliczni badacze, którym udało się zajrzeć do tych ksiąg. Teksty drukowane, będące własnością najpierw Kozierowskiego, potem Archiwum Państwowego

34 Zob.: M. Janeczek, Archiwalne starodruki - mało znany wycinek zespołu Akt Braci Czeskich, „Przegląd Archiwalno-Historyczny” 2014, t. 1, s. 183-208. 
w Poznaniu, zostały ostatecznie rozproszone w 1961 r. Jednym z celów niniejszego artykułu jest zlokalizowanie obecnego miejsca ich przechowywania. Tropienie starych druków według proweniencji nie jest sprawą łatwą, gdyż biblioteki nie zawsze ujawniają dawnych właścicieli w katalogach. Dodatkowym utrudnieniem jest brak dokumentacji na temat przekazywanych w przeszłości ksiąg, w szczególności protokołów zdawczo-odbiorczych. Pomimo tych niedostatków mamy pewność, że proces rozpraszania biblioteki Kozierowskiego rozpoczął się dużo wcześniej, przynajmniej w 1954 r. Dowody znajdujemy w księgach inwentarzowych biblioteki PTPN, jednocześnie nie potrafimy uzasadnić, skąd wzięły się w tamtejszej książnicy niektóre druki po Kozierowskim o niskich numerach, nadawanych nabytkom w okresie międzywojennym. Możliwym do zaakceptowania wytłumaczeniem jest to, że mogły to być dublety, których profesor pozbył się przed wybuchem II wojny światowej ${ }^{35}$.

Lista starodruków, w posiadanie których wszedł ks. Stanisław Kozierowski, a następnie przekazał do archiwum poznańskiego, nie jest długa, wobec czego warto pokazać ją tu w całości. Leon Siuchniński w żaden sposób nie uporządkował księgozbioru przed dokonaniem spisu, toteż i starodruki nie były osobno wydzieloną grupą materiałów bibliotecznych; zapewne odnotowywał książki po kolei, tak jak ustawione były na regałach. Jego wykaz (ewidentnie pisany w pośpiechu, na co wskazują liczne skreślenia i nanoszone poprawki) zawiera opis skrócony książek: autora, tytuł, miejsce i rok wydania; nie zawsze jest tak dobrze, czasem w ogóle brakuje adresu wydawniczego i wówczas druk - w przypadku większej liczby wydań - jest nie do zidentyfikowania. W celu wyłonienia starodruków spis przejrzano w całości. Ponieważ księgozbiór Kozierowskiego został po 1960 r. definitywnie rozproszony, przeto dość istotną sprawą staje się wskazanie obecnego miejsca przechowywania starodruków. Przedstawiony w dalszej części artykułu wykaz dzieł ułożony został alfabetycznie, sam opis bibliograficzny zaś obejmuje: nazwę osobową autora lub redaktora, tytuł (często w formie skróconej), oznaczenie tomu, adres wydawniczy i umieszczone w nawiasie okrągłym dane fizyczne. Na końcu podano numer pozycji w spisie wykonanym przez Siuchnińskiego oraz nazwę instytucji, która obecnie przechowuje określony starodruk, wraz z sygnaturą.

${ }^{35}$ Dobrym przykładem jest tu Wymowa i poezya dla szkót narodowych Grzegorza Piramowicza. Siuchniński notuje w spisie tylko część pierwszą, tymczasem w zbiorach PTPN są wszystkie trzy części (w dwóch tomach). Dodatkowo egzemplarz ten ma niski numer inwentarzowy (41382). 
1. Agricola Conrad, Concordantiae Bibliorum emendatae ac ferè novae, das ist: Biblische Concordantz, oder Verzeichnus der fürnehmsten Hörter, wie auch aller ... Geschichten..., Hrsg. C. Zeis, Johann Friderici, Johann Nikolaus Humm und Johann Görlin, Franckfurt am Mayn 1674, ([924] k. ; 2º). Poz. 3528. Lokalizacja: nieznana.

2. Ambrosius (Mediolanensis), Divi Ambrosii mediolanensis episcopi Officiorum Liber, Gregorius de Gregoriis, Venetiis 1514, (87 k. ; 8). Poz. 3920. Lokalizacja: nieznana.

3. Antonius (de Rampegollis), Figuraru[m] biblie opus co[n]ducibile $\mathcal{E} p$ [er] utile..., Johannes Knobloch, Argentine 1516, ([20], cclvi k. ; 8). Poz. 3920. Lokalizacja: nieznana.

4. Batteux Charles, Einleitung in die schönen Wissenschaften..., Bd. 1-4, Bearb. K. W. Ramler, Weidmanns Erben und Reich, Leipzig 1769, (Bd. 1: XXVI, 464 s., [3] k. - Bd. 2: 412 s., [2] k. - Bd. 3: 362 s., [2] k. - Bd. 4: 427 s., [2] k. ; $8^{\circ}$ ). Poz. 602. Lokalizacja: PTPN (sygn. 100442.I).

5. Biblia: Hē Palaia Diathēkē Kata Tus Ebdomēkonta. Vetus Testamentum Græcum Ex versione Septuaginta Interpretum, Cum Libris Apocryphis, juxta exemplar Vaticanum Romæ editum, \& Anglicanum Londini excusum..., Hrsg. M.J. Clauer und J.T. Klumpf, Vorr. J. Frick, Johannes Christophorus Königius - Christophorus Fleischerus, Goslariae - Lipsiae 1697, ([6] k., 56 s., [1] k., 752 s., [1] k., s. 753-3018 [i.e. 1218], 186 s., [4] k., 447 s. ; $8^{\circ}$ ). Poz. 3542. Lokalizacja: nieznana.

6. Birkowski Fabian, Kazania na niedziele y Swięta doroczne..., t. 2, Andrzej II Piotrkowczyk, Kraków 1628, (9 k., 782 s., 5 k. ; 2º). Poz. 3531. Lokalizacja: nieznana.

7. Buchanan George, Paraphrasis Psalmorum Davidis poetica..., Hrsg. M. A. Flaminio, Josias Rihelius, Argentorati 1575, ([12], 403, [1] s. ; $8^{\circ}$ ). Poz. 3547. Lokalizacja: PTPN (sygn. 41507.I).

8. Busenbaum Hermann, Medulla Theologiae Moralis Facili ac perspicua methodo resolvens Casus Conscientiae..., Typis Theodori Raesfeldt, Monasterii Westphaliae 1667, ([34] k., 960 s. ; 12º). Poz. 3593. Lokalizacja: nieznana.

9. Cicero Marcus Tullius, Cicero's Geist und Kunst. Eine Sammlung der geistreichsten, vollendetsten und gemeinnützigsten Stücke aus den Ciceronianischen Schriften, Bd. 1-2, Hrsg. J. C. G. Ernesti, Kasper Fritsch Erben, Leipzig 1799-1800, (Bd. 1: XXX, 362 s. - Bd. 2: IV, 393 s. ; 8º). Poz. 2963. Lokalizacja: nieznana.

10. Cicero Marcus Tullius, Epistolae ad diversos, familiares aliis vocatae ad codices accuratissimos emendatae, Orphanotropheum, Halae 1745, ([2] k., 608 s. ; $\left.8^{\circ}\right)$. Poz. 2964. Lokalizacja: nieznana.

11. Comalada Miguel, Desiderosus Abo Scieszka Do Milosci Bozey, y do Doskonałośći zywota Chrześćianskiego. Dialog dziwnie nabożny, y ućieszny: z Hiszpańskiego na Włoski, Francuski, Niemiecki, Niderlandski y Laćinski ięzyk a potym 
y na Polski przełożony..., przeł. K. Wilkowski, wyd. K. Sakowicz, Andrzej II Piotrkowczyk, Kraków 1625, (22 k., 256 s., 8 s. ; 8º). Poz. 3901. Lokalizacja: nieznana.

12. Corneille Thomas, Oeuvres de T. Corneille, T. 9, chez la veuve Bordelet, Paris 1758, ([2] k., 282 s., [3] k. ; 12º). Poz. 3401. Lokalizacja: PTPN (sygn. 100772.I).

13. Corpus Iuris Canonici Emendatum et Notis Illustratum...,Hrsg. G.P. Lancellotti, [s.n.], Lugduni 1605, ([34] k., 1272 kol. ; 4º). Poz. 3587. Lokalizacja: PTPN (sygn. 10533.II).

14. Decretales D. Gregorii Papae IX. Suae Integritati Restitutae. Cum Privilegio Gregorij XIII. Pont. Max. ..., [s.n.], Lugduni 1605, ([10] k., 754 kol. ; $4^{\circ}$ ). Poz. 3588. Lokalizacja: PTPN (sygn. 10302.II).

15. Derjakubowicz Dominik, Xiężyc w petni sławy y wieczney Pamięci ... Smiertelna lunacya do ostatniey kwadry nakłoniony ... Michat Serwacy Xiaze Korybuth Wiśniowiecki ... na ręku ... Janusza Lubartowicza ... Sanguszka ... złozony a przy pogrzebowey rewolucyi ... przez ... kaznodzieyska expressya ... reprezentowany..., W Drukarni Akademickiey, Kraków [1747], ([18] k. ; 2º. Poz. 3765. Lokalizacja: nieznana.

16. Ducry Sébastien Joseph, Amusement curieux et divertissant, propre a égayer l'espirit..., Nicolas Labbey, Rouen 1787, (171 s., [1] s. ; $\left.12^{\circ}\right)$. Poz. 4044. Lokalizacja: PTPN (sygn. 6603.I).

17. Epictetus, Enchiridium una cum Cebetis Thebani Tabula Graec. \& Lat. cum notis Wolfii, Casauboni, Caselii \& aliorum..., Bearb. A. van Berkel, Apud Viduam Gerardi De Jager, Delphis Batavorum 1683, ([16] k., 280 s., [1] k.; $8^{\circ}$ ). Poz. 2980. Lokalizacja: PTPN (sygn. 12326.I).

18. Faber Matthias, Auctarium Operis Concionum Tripartiti, P. 1-2: Adiectum ab eiusdem Operis..., Apud Lucam Kupisz, Cracoviae 1647, (P. 1: [5] k., 603, [1] s. - P. 2: [2] k., 280 s., [4] k. ; $\left.2^{\circ}\right)^{36}$. Poz. 3530. Lokalizacja: nieznana.

19. Fidetowicz Marcin, Philosophia Ex Campo Saphirino ad Campum Albosanguineum gloriose Procedens Seu Conclusiones Ex VniversaPhilosophia Speculativa Ad Mentem D. Thomae Doctoris Angelici Concinnatae Et Praesidente..., promotor K. Krzykawski, Typis Universitatis, Cracoviae [1690], ([9] k. ; $2^{\circ}$ ). Poz. 3508. Lokalizacja: BUAM (sygn. SD 3706 III).

20. Fleury Claude, Institutiones iuris ecclesiastici..., Ex Typographia Balleoniana, Venetiis 1753, (573, [1] s. ; $\left.8^{\circ}\right)$. Poz. 3590. Lokalizacja: nieznana.

21. Guilliaud Claude, In Canonicas Apostolorum Septem epistolas, collation..., apud Ioanne[m] Roigny, Parisiis 1552, ([18], 200 k. ; 8). Poz. 3546. Lokalizacja: PTPN (sygn. 100288.I).

${ }^{36}$ Nie mam pewności, czy chodzi o tę publikację, gdyż oryginalny zapis Siuchnińskiego wygląda tak: „Pater Matthias Faber [Conciones in singules dominicas] 1647”. 
22. Guilliaud Claude, In omnes divi Pauli Apostoli epistolas collatio Iuxta eruditorum sententiam facta, apud Ioanne[m] Roigny, Parisiis 1550, ([20], 416 k. ; $8^{\circ}$ ). Poz. 3546. Lokalizacja: PTPN (sygn. 100287.I).

23. Hoffberg Carl Fredrik, Anwisning til naturens kännedom. D. 1: Om wäxtriket..., Johan Georg Lange, Stockholm 1768, (81, [31] s. ; 8). Poz. 2723. Lokalizacja: nieznana.

24. Homerus, Iliada, księga 1, przeł. F. K. Dmochowski, Drukarnia pijarów, Warszawa 1800, ([20], 331 s. ; $\left.8^{\circ}\right)$. Poz. 2928. Lokalizacja: nieznana.

25. Horatius Flaccus Quintus, Les poésies d'Horace, traduites en françois..., t. 1, trad. C. Batteux, chez Nicolas Desaint \& Charles Saillant, Paris 1763, (XXIV, 389 s., [6] k. ; $8^{\circ}$ ). Poz. 2968. Lokalizacja: nieznana.

26. Horatius Flaccus Quintus, Poemata omnia ad haec, alia nonnulla ipsi authori non parum lucis adferentia studio ac diligentia Henrici Glareani recogn., eiusdemque annotationibus illustr. Adiecta sunt praeterea ubique argumenta $\mathcal{E}$ carminum rationes, Hrsg. H.L. Glareanus, Joannes Faber Emmeus, Friburgi Brisgoiae 1540, ([8] k., 383, [1] s., [4] k., 164 s., [2] k. ; 8³) 37. Poz. 2967. Lokalizacja: nieznana.

27. Hugo (de Sancto Caro), Sacrorum Bibliorum Vulgatae Editionis Concordantiae..., Hrsg. J.G. Silberbauer, Apud Martinum Endterum, Viennae 1714, $\left(15,1411\right.$ s. ; $\left.4^{\circ}\right)$. Poz. 3533. Lokalizacja: nieznana.

28. Kant Immanuel, Metaphysische Anfangsgründe der Naturwissenschaft, Johann Friedrich I Hartknoch, Riga 1787, (XXIV, 158 s. ; $8^{\circ}$ ). Poz. 3000. Lokalizacja: BK PAN (sygn. 228575).

29. Knapski Grzegorz, Słownik polsko-łaciński..., t. 1, oprac. B. Woronowski, Drukarnia Societatis Jesu, Kalisz 1769, ([22] k., 793 s. ; $8^{\circ}$ ). Poz. 1356. Lokalizacja: APP (sygn. 01.H.19).

30. Labata Francisco, Apparatus Concionatorum, Seu Locorum Communium ad Conciones..., t. 2, Johannes Crithius, Coloniae Agrippinae 1619, ([4] k., 982 s., [16] k. ; $4^{\circ}$ ). Poz. 3532. Lokalizacja: nieznana.

31. Meißner August Gottlieb, Alcibiades, Th. 2-4, Johann Gottlob Immanuel Breitkopf, Leipzig 1785-1788, (Th. 2: [2] k., 360 s. - Th. 3: [2] k., 376 s. Th. 4: [15] k., 452 s. ; 8). Poz. 2943. Lokalizacja: PTPN (sygn. 6617.I).

32. Metastasio Pietro, Opere del signor ab. Pietro Metastasio poeta cesareo, settima edizione con una nuova aggiunta di altre sue opere postume che finora non sono state stampate, t. 2, Antonio Zatta, Venezia 1800, (335, [1] s. ; 12º). Poz. 4045. Lokalizacja: PTPN (sygn. 100373.I).

33. Nepos Cornelius, Vulgo Aemilii Probi, quae extante museo Jo. Andreae Bosii, in qua quid praestitum sit, Syllabis praefationi subiectus docebit, Hrsg. J.A. Bose,

${ }^{37}$ Nie mam pewności, czy chodzi o tę publikację, gdyż oryginalny zapis Siuchnińskiego wygląda tak: "Q. Horatii Flacii epistolae Friburgi Brisg. 1540”. 
Christian Kirchner und Kaspar Freyschmidt, Lipsiae 1657, ([25], [401] k., 25 s., [116], [1] k., 74 s., [1] k. ; $8^{\circ}$ ). Poz. 2966. Lokalizacja: nieznana.

34. Neue auserlesene Kanzelreden über die wichtigsten Wahrheiten der Religion..., Th. 1-2, Übers. G. Trautwein, Gebrüdern Veith, Augsburg 1770, (Th. 1: [4] k., 358 s. - Th. 2: [2] k., 394 s., [1] k. ; 8). Poz. 3992. Lokalizacja: nieznana.

35. Ovidius Naso Publius, Tristium Libri V. Et Epistolarum Ex Ponto Libri IV. Captui studiosae Juventutis Accommodati, Oder: Deutliche und nach dem Begriff der studirenden Jugend eingerichtete Erklärung der Bücher Tristium und Ex Ponto des Römischen Ritters und Poeten Ovidii..., Hrsg. E. Schneider, Verlegts Mertz und Mayer, Augspurg 1732, ([14] k., 609 s., [31] k. ; $8^{\circ}$ ). Poz. 2974. Lokalizacja: nieznana.

36. PallasPeterSimon, SammlungenhistorischerNachrichtenüberdie Mongolischen Völkerschaften..., Th. 1, Kayserlichen Akademie der Wissenschaften, Sankt Petersburg 1776, ([1] k., XIV, 232 s., [5], VII k. ; 4º). Poz. 1843. Lokalizacja: nieznana.

37. Panvinio Onofrio, Beuther Michael, Inauguratio, coronatio, electioque aliquot imperatorum..., Andreas Wechel Erben und Johann Aubry Erben, Hanoviae 1613, ([2] k., 284 s. ; $8^{\circ}$ ). Poz. 935. Lokalizacja: BK PAN (sygn. 127107).

38. Piramowicz Grzegorz, Wymowa i poezya dla szkót narodowych, cz. 1-3, Drukarnia Szkoły Głównej Koronnej, Kraków 1792, (cz. 1: [6] k., XIV, 403 s. - cz. 2: [9], 406-939 s. - cz. 3: [4], 941-1126 s. ; 8º. Poz. 3903. Lokalizacja: PTPN (sygn. 41382.I).

39. Plinius Caecilius Secundus Gaius, Epistolae et Panegyricus..., Hrsg. C. Cellarius, Johannes Fridericus Gleditschius, Lipsiae 1693, ([19] k., 758 s., [40] k. ; 12). Poz. 2969. Lokalizacja: PTPN (sygn. 100420.I).

40. Retzius Anders Jåhan, Inledning til djur-riket, efter herr archiatern och riddaren Carl von Linnés lärogrunder, Carl Stolpe, Stockholm 1772, ([8] k., 272 s. ; $8^{\circ}$ ). Poz. 2723. Lokalizacja: nieznana.

41. Thomas a Kempis, De Imitatione Christi, Libri Quatuor; Ex recensione Heriberti Rosweydi Societatis Jesu, Typis Collegii Societatis Jesu, Brunsbergae 1719, (347 s., [3] k., $8^{\circ}$ ). Poz. 3927. Lokalizacja: nieznana.

42. Valerius Maximus, Dictorum Factorumque Memorabilium Libri IX..., Hrsg. J. Minell, Ex Officina Arnoldi Leers, Roterodami 1671, ([12] k., 554 s., [13] k.; 12º). Poz. 2977. Lokalizacja: PTPN (sygn. 100544.I).

43. Voltaire, Essai Historique Et Critique Sur Les Dissentions Des Eglises De Pologne Par Joseph Bourdillon..., [s.n.], Basle 1767, (54 s. ; $8^{\circ}$ ). Poz. 3820. Lokalizacja: nieznana.

44. Zawadzki Benedykt, Kazania na Niedziele Doroczne, Dla większey Czći y Chwaty Boga w Troycy iedynego..., t. 1, Drukarnia Collegium Scholarum Piarum, Warszawa 1700, ([4] k., 504 s., [7] k. ; 2). Poz. 3529. Lokalizacja: nieznana. 
Wykaz starodruków - według zweryfikowanych informacji - liczy 44 pozycje. Nie ma pewności, że ze spisu Siuchnińskiego wyłowiono wszystkie starodruki, a to dlatego, iż opis niektórych książek, a w szczególności adligatów pozostawia wiele do życzenia. Przykładowo archiwista pod numerem 3063 zapisał: „Klocek zawierający 8 utworów Goethego, Szekspira, Lessinga i Moliera". Dopóki w którejś z bibliotek nie zostanie ujawniony taki zbiór (jednoznacznie opieczętowany), dopóty będą trapiły nas wątpliwości, czy te druki zostały wydane przed $1801 \mathrm{r}$. We wspólnej oprawie z dziełem Poemata omnia... (poz. 2967) zachował się być może postinkunabuł drukowany w Wenecji w 1501 r.; sam zapis Siuchnińskiego - „M. Val. Martialis epigrammata" - jest bez znaczenia w sytuacji, kiedy utwory poetyckie Rzymianina często w owym czasie (XVI w.) wydawano, tu jednak zgadzałby się (prócz datowania) również format (in octavo) obu dzieł. Jeszcze trudniejsze do zidentyfikowania są trzy klocki (poz. 3766-3768) zawierające mowy pogrzebowe, bo wszystko, co o nich wiemy, sprowadza się do tego, że w pierwszym mieściło się sześć dzieł, w drugim - jedenaście, a w trzecim - dwadzieścia dwa. Podobnie nie udało się ustalić metryki kancjonału opisanego słowami „Panie Boże Ciebie chwalimy", który zarejestrowany został w spisie pod numerem 3885. Tak więc rzeczywisty obraz zasobu biblioteki Kozierowskiego jest dość mętny i wymagałby pogłębionych badań proweniencyjnych, na które przy obecnym stanie katalogów bibliotecznych w Polsce trudno sobie pozwolić.

Nie oznacza to, że temat został zaniechany. Przeprowadzono kwerendę w następujących archiwach i bibliotekach: Archiwum Państwowym w Poznaniu oraz w gnieźnieńskim Oddziale tejże placówki, Archiwum Państwowym w Bydgoszczy, Archiwum Archidiecezjalnym w Poznaniu i Gnieźnie, Archiwum Głównym Akt Dawnych, Bibliotece Uniwersyteckiej w Poznaniu, Bibliotece Raczyńskich, Bibliotece Poznańskiego Towarzystwa Przyjaciół Nauk, Bibliotece Instytutu Slawistyki PAN, Bibliotece Kórnickiej PAN, Książnicy Kopernikańskiej oraz w Bibliotece Uniwersyteckiej w Toruniu. Wstępne rozpoznanie objęło także Bibliotekę Narodową i Bibliotekę Uniwersytecką w Warszawie. Druki po Stanisławie Kozierowskim odnaleziono w Archiwum Państwowym w Poznaniu (poz. 29), Bibliotece UAM (poz. 19), Bibliotece PTPN (poz. 4, 7, 12-14, 16-17, 21-22, 31-32, 38-39, 42) i Bibliotece Kórnickiej (poz. 28, 37). Nie powiodło się ustalenie obecnej lokalizacji 26 dzieł, co wywołuje frustrację tym większą, że do osiągnięcia celu wystarczyłyby jedynie rozbudowane katalogi on-line.

Tak duża grupa książek z nieznaną lokalizacją budziła podejrzenie, że może trafiły one jakimś sposobem do rąk prywatnych. Potwierdziła to w korespondencji elektronicznej prof. Alicja Pihan-Kijasowa: „Wiem, że przynajmniej część z tych książek trafiła do Antykwariatu im. J.K. Żupańskiego w Poznaniu i na aukcje prowadzone przez ten antykwariat. Przyjmowaniem i wyceną książek zajmował się wówczas (nieżyjący już) pan Dominikowski. 

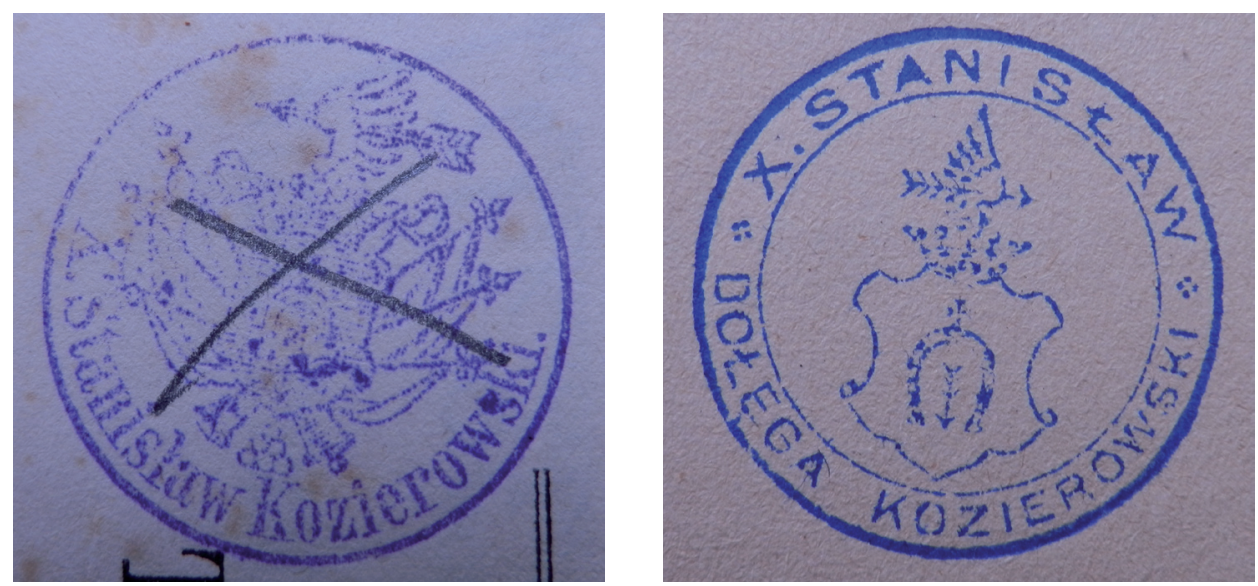

Fot. 2 / Fot. 3. Pieczęcie, którymi oznaczał książki ks. Stanisław Kozierowski

Może gdzieś zachowały się katalogi tych aukcji z lat 60. (pierwsze aukcje, zdaje się, katalogów nie miały, ale następne już tak). Może tą drogą coś uda się ustalić". Wielotygodniowe poszukiwania nie dały rezultatu. Z rozmowy telefonicznej, jaką przeprowadziłem z Jerzym Rybarczykiem, właścicielem firmy, dowiedziałem się, że Wojciech Dominikowski pracował w antykwariacie dopiero od 1969 r., więc to nie on prowadził wycenę starodruków proboszcza winnogórskiego. Przygotowywane na powielaczu katalogi aukcyjne rzeczywiście istniały, jednak żadna instytucja w Poznaniu dziś już nimi nie dysponuje, co definitywnie zamyka ten temat.

Ks. Stanisław Kozierowski oznaczał swoje książki odręcznie wykonanym podpisem lub pieczęciami. Pozycje 22. i 42. zawierają następującą notatkę: „Ks. Stanisław Kozierowski Skórzewo 1928”, wykonaną czarnym atramentem. Tym samym przyrządem sporządzone zostały napisy $\mathrm{w}$ zdefektowanym druku oznaczonym liczbą 14, a także $\mathrm{w}$ druku przyporządkowanym do liczby 13: „Ks. Stanisław Dołęga Kozierowski Winnagóra 21/V 1930”. Do znakowania książek duchowny używał też stempli pieczętnych, które maczał w niebieskim lub fioletowym tuszu. Częściej spotykamy w książkach odcisk okrągłej pieczęci o treści: „X. STANISŁAW DOŁĘGA KOZIEROWSKI”, aniżeli wyrobionej około 1938 r. pieczęci podłużnej z napisem: „Ks. Kanonik Prof. Uniw. Pozn. Stanisław Dołęga-Kozierowski Członek Pol. Akad. Umiej. Winnagóra, p. Miłosław". Pierwszą z nich zarejestrowano w dwunastu drukach (poz. 4, 7, 12-14, 17, 28-29, 31-32, 37-38), drugą - w trzech (poz. 16, 19, 39). Znak proweniencyjny - zgodnie ze zwyczajem - znajduje się najczęściej w początkowej części książki: na karcie ochronnej, przedtytułowej lub tytułowej, rzadziej na kolejnych kartach. Bywa, że w jednym dziele właściciel odciskał pieczęcie kilka razy na przypadkowo wybranych kartach. 


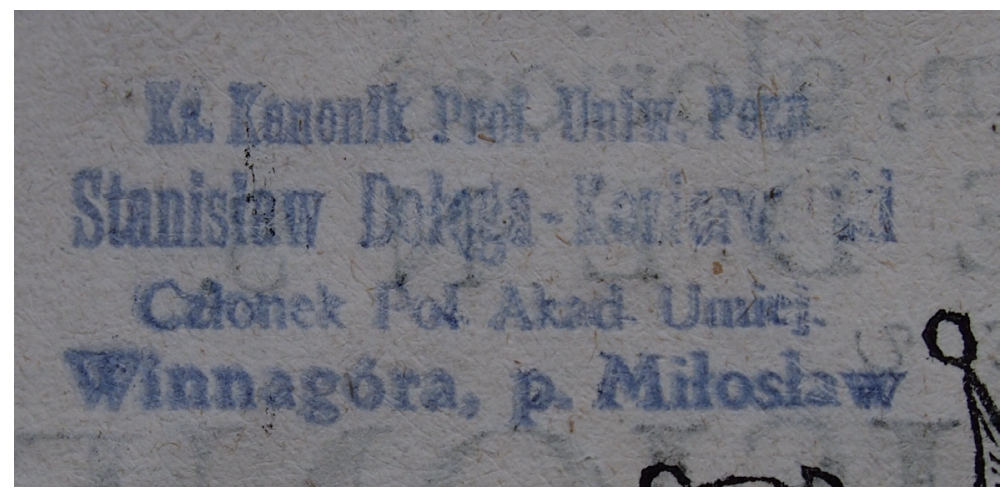

Fot. 4. Pieczęć, którą oznaczał książki ks. Stanisław Kozierowski

O ile nowe druki Kozierowski gromadził dla doskonalenia własnego warsztatu w sposób przemyślany, o tyle stare druki nabywał w sposób przypadkowy, co można wytłumaczyć ograniczoną podażą; brał po prostu to, co akurat było do zdobycia. Z pewnością nie dziwi obecność w bibliotece księdza profesora książek teologicznych (poz. 1-3, 5-7, 11, 15, 18, 21-22, 27, 30, 34, 41, 44), historycznych (poz. 33, 36, 42), filozoficznych (poz. 8, 17, 28, 43) i językoznawczych (poz. 29, 38), ale już literatura piękna (poz. 4, 9-10, 12, 16, 24-26, $31-32,35,39$ ) trochę zaskakuje, dokumenty przyrodnicze zaś (poz. 23, 40) - to rzecz zupełnie nieoczywista.

Najstarszym drukiem zdobytym przez Kozierowskiego był Divi Ambrosii mediolanensis episcopi Officiorum Liber z 1514 r. (poz. 2). W sumie z XVI w. pochodzi sześć dzieł, z XVII - szesnaście, i najwięcej z XVIII - dwadzieścia dwa. Proboszcz Winnej Góry posiadał najwięcej starodruków w języku łacińskim (dwadzieścia dwa), osiem dzieł drukowano po niemiecku, siedem - po polsku; odnotowano jeszcze cztery teksty w języku francuskim, dwa - w języku szwedzkim, i jeden - w języku włoskim.

Na skutek decyzji dawnych władz o relokacji książek poznańska placówka na zawsze utraciła wiele cennych starodruków. Oczywiście, zrozumiałe są czynniki mające wpływ na rozbicie księgozbioru, niemniej wielka szkoda, że podjęta została taka decyzja, bo zbiór biblioteczny ks. Stanisława Kozierowskiego powinien mieć wspólną lokalizację, tak jak inne wielkie kolekcje zasłużonych dla nauki osób. Można więc zaryzykować tezę, że najbardziej kłopotliwym rodzajem nabytków dla bibliotek i archiwów są dary, bo dla nich zawsze brakuje miejsca na regałach. 
Michał Janeczek

\title{
Utracony księgozbiór ks. Stanisława Kozierowskiego
}

\begin{abstract}
Streszczenie
O ks. Stanisławie Kozierowskim, jednym z najbardziej zasłużonych naukowców wielkopolskich, powstało wiele artykułów. Badaczy interesował w szczególności życiorys jednego z założycieli poznańskiego Uniwersytetu, inspirował niezwykły dorobek onomastyczny i genealogiczny, pociągał portret psychologiczny człowieka, który bez reszty poświęcił się pracy twórczej. Bardzo mało uwagi poświęcali natomiast wielkiej kolekcji książek, która rozsławiła imię Kozierowskiego na równi z jego dorobkiem naukowym. Tuż przed śmiercią przekazał on całą bibliotekę Archiwum Państwowemu w Poznaniu, które w czasie wojny poniosło dotkliwe straty materialne. Wśród blisko 7000 tomów znajdowało się kilkadziesiąt starodruków. Na skutek decyzji dawnych władz Archiwum o relokacji książek poznańska placówka na zawsze utraciła także te najcenniejsze materiały. W niniejszym artykule ukazano kulisy owej donacji, a także podjęto próbę ustalenia obecnej lokalizacji starodruków. Integralną częścią artykułu jest bibliograficzny spis zabytkowych książek należących w przeszłości do Kozierowskiego, który być może ułatwi odnalezienie 26 dzieł z tejże listy.
\end{abstract}

Słowa kluczowe: Kozierowski Stanisław, Archiwum Państwowe w Poznaniu, kolekcje prywatne, starodruki, biblioteka, proweniencja

\section{Father Stanisław Kozierowski's lost book collection}

\begin{abstract}
Much has been written about father Stanisław Kozierowski, one of the most distinguished scientists of Greater Poland. Scholars were mainly interested in his biography as one of the founding fathers of the Poznań University, inspired by his extraordinary achievements in the fields of onomastics and genealogy, and attracted by the personality of a man who dedicated his whole life to creative work. Little attention was paid to the large book collection, which Kozierowski was famous for almost as much as for his scientific achievements. Right before his death, he donated his book collection to the National Archive in Poznan, which suffered great losses during the war. Among nearly 7000 volumes, there were several dozen old prints. Following the decision of the Archive's former authorities to relocate the collection, the Poznan branch lost these items, including the most valuable ones, forever. This article presents the story behind this donation and attempts to establish where these old prints are at the moment. A bibliographical list of historic books from the Kozierowski collection is an essential part of the article, and might aid researchers in finding 26 items from the list.
\end{abstract}

Keywords: Kozierowski Stanisław, National Archive in Poznań, private collections, old prints, library, provenance 